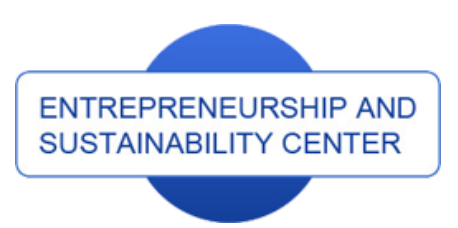

Publisher

http://jssidoi.org/esc/home
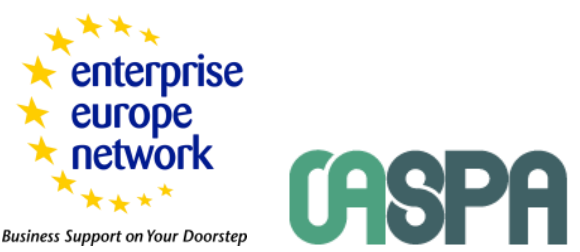

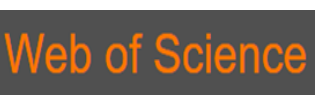

1 Clarivate

Analytics

\title{
MARKET PECULIARITIES OF NATURAL GASS: CASE OF THE PACIFIC REGION
}

\author{
Larisa Shakhovskaya $^{1}$, Elena Petrenko ${ }^{2}$, Alexandr Dzhindzholia ${ }^{3}$, Victoria Timonina ${ }^{4}$ \\ ${ }^{1,3,4}$ Volgograd State Technical University, Lenin avenue 28, 400005 Volgograd Russia \\ ${ }^{2}$ Plekhanov Russian University of Economic, Stremyanny lane 36, 117997, Moscow, Russia \\ E-mails: ${ }^{1}$ mamol4k@yandex.ru ${ }^{2}$ petrenko_yelena@bk.ru, \\ ${ }^{3}$ poligraf@mail.ru, ${ }^{4}$ timonina.virka96@yandex.ru
}

Received 20 August 2017; accepted 10 January 2018; published 30 March 2018

\begin{abstract}
In this article are considered by authors the technological, resource and economic capacity of the Far East, the first stages of a cooperation between Russia and the largest gas importers in the Pacific Rim are described, the main projects and fields contributing to the development of a cooperation between the countries are also considered. Statistical methods of the analysis act as methodological base of a research. In modern conditions in relation to the energy sector of Russia (imposition of sanctions by the western countries) there is a reorientation of export deliveries to the EU to Asia-Pacific countries. In these conditions the Far East of Russia acts as a large oil and gas source which has advantages and opportunities to compete in the Asian market, using not only the favorable investment climate, but also the infrastructure developed for today's time. The carried-out analysis showed that Russia is the largest suppliers in the market of AsiaPacific countries. Constantly interest in the Russian energy resources in the Asian market grows. It is connected with a geographical location of Russia, with high inventories of hydrocarbons in the Far East, safety of deliveries, low policy risks, etc.
\end{abstract}

Keywords: natural gass, market, Asia-Pacific countries, Russia, projects, competition, import, consumption

Reference to this paper should be made as follows: Shakhovskaya, L.; Petrenko, E.; Dzhindzholia, A.; Timonina, V. 2018. Market peculiarities of natural gass: case of the Pacific Region, Entrepreneurship and Sustainability Issues 5(3): 555-564. . https://doi.org/10.9770/jesi.2018.5.3(11)

JEL Classifications: Q31, Q41 


\section{Introduction}

Availability and affordability of energy are just several facets of energy security of any country (e.g. Tvaronavičienè et al. 2017; Melas et al. 2017). Growing demand on energy makes those issues even more urgent.

The gas consumption in Asia-Pacific countries increases prompt rates. For the last 10 years demand for energy resources increased by $6 \%$ (more than twice). According to forecasts, demand in China by 2030 will increase to 240 billion cubic meters from which more than a half will be imported. In addition to China, demand will increase in India, South Korea and Japan. Cost value of production and gas transportation of the acting suppliers in AsiaPacific countries obviously differ. Owing to limitation of a possibility of building-up of own inventories, the energy policy of Asia-Pacific countries is aimed at the development of a cooperation with gas exporting countries: Russia, Australia, Indonesia, countries of the Middle East. However considering transportation distance, level of cost of resources, the number of infrastructure projects, there is a question: what gas will be competitive in this market?

\section{Analytivcal part}

The share of Russia in the world market of gas doesn't exceed 5\%, however the state energy strategy provides increase in an indicator up to $12 \%$ by 2035 of the total amount of the world market. It will become possible only in case of a gas production growth in volumes twice in comparison with the indicator fixed in 2016 (Ttable 1).

Table 1. Gas production in Russia, billion cubic meters

\begin{tabular}{|c|c|}
\hline Year & Gas production, billion cubic meters \\
\hline 2010 & 650,7 \\
\hline 2011 & 670,7 \\
\hline 2012 & 654,5 \\
\hline 2013 & 668,2 \\
\hline 2014 & 641,9 \\
\hline 2015 & 635,5 \\
\hline 2016 & 640,7 \\
\hline
\end{tabular}

Source: $\underline{\text { htp://minenergo.gov.ru/node/1215 }}$

In Russia there is a set of large projects which purpose to expand presence of Russia in the world market of natural gas. One of them - "Sakhalin II" (Sakhalin Energy) which shareholders are Gazprom (50\%), Shell (27,5\%), "Mitsui" (12,5\%) and Mitsubishi (10\%). Two processing lines annually receive about 14,9 billion cubic meters of liquefied natural gas, 11 million tons which it is exported to the countries of Asia-Pacific region. In 2015 it became known that Sakhalin Energy plans to construct the third processing line capacity to 5,4 million tons/year. The company signed development agreements of the project with the Shell Global Solutions International company and the Russian design institute "Giprogaztsentr". 
The International Journal

ENTREPRENEURSHIP AND SUSTAINABILITY ISSUES

ISSN 2345-0282 (online) http://jssidoi.org/jesi/

2018 Volume 5 Number 3 (March)

http://doi.org/10.9770/jesi.2018.5.3(11)

"Yamal LNG" the project which is at an implementation stage which capacity reaches 16,5 million tons/year, it is created in a cooperation with the companies: Total and CNPC-of 20\%, Silk Road Fund-9, $9 \%$ (Kutuzova, 2016). Strategically advantageous position of the project, according to many experts, will allow to export the extracted gas not only to Europe, but also to Asia-Pacific countries In 2014 the project faced a financing problem. Investment attraction became complicated after entering of the USA of sanctions. However, at the end of 2014 the project received 150 billion rubles from "National welfare fund" which purchased the issued bonds "Yamal LNG". In 2015 the "Novatek" company agreed with the Chinese "Fund of the Silk way" about provision of a loan about 730 million euros for financing of a construction. After the loan agreement the fund of China acquired 9\% of shares of Yamal LNG. According to the head of the Novatek company Leonid Mikhelson: "Signing of binding documents selling a share in the project of "Yamal LNG" is an important step to implementations of our longterm development strategy. As a result of closing of the transaction we will reach target structure of shareholders which is optimum and will promote planned financing of the project and its further successful implementation"*.

"Rosneft" company together with "ExxonMobil" realizes the project on gas production - "The Far East LNG". The project startup in operation is planned for 2018 - 2019. According to some information, the design capacity will make 5 million tons/year, which source of raw materials will form - fields of the "Sakhalin-I" project and inventories of "Rosneft" in the Far East. Within only the "Sakhalin-I" project about 7 billion cubic meters of natural gas are extracted, having realized the project and using inventories in the Far East, the company will increase a production indicator at least twice.

It is more than a half of the territories of Eastern Siberia and the Far East have extensive inventories of hydrocarbons. In Eastern Siberia geological inventories are estimated at 92,2 billion tons. In this territory 68 fields were found (from them five "unique" fields which inventories exceed 300 million tons or 500 billion cubic meters). According to prospecting services, in a subsoil of the region there is an equal amount of oil and gas, however on the taken resources gas $(80 \%)$ prevails. Despite this percentage ratio, calculations of the companies show that resource base of oil of Eastern Siberia in case of the correct operation and further development, is capable to provide oil extraction by 2020 approximately on 50 million tons in a year.

In the Far East geological inventories are estimated at 18,9 billion tons, annual gas production in this territory constitutes more than 1,5 billion cubic meters. Oil extraction is conducted since 1923 therefore extent of exploration of resources reached 55\%, and amounts of the extracted oil make 2,7 million tons. The main resources of the Far East are located on the water area: "North - Sakhalin" shelves and "Magadansk - West - Kamchatka". The largest projects in the Far East are "Sakhalin -1 " and "Sakhalin-II" which provide up to 50\% and more oil extraction and higher than $83 \%$ of production of LNG. The further prospect of development of natural gas production is connected with a construction of a trunk gas pipeline "Force of Siberia" as which resource base earlier not researched "Chayadinsky" field will act. Oil refining is performed in two largest oil refineries in the Far East - "Komsomolsk Refinery" and "Khabarovsk refinery". General capacity of the plants on data of 2016 left 12,9 million tons. However, in the territory the unique gas liquefaction plant - "Sakhalin -2" which capacity is higher than 9,6 million tons functions. Thus, the structure mineral - source of raw materials of the Far East allows to gain steam in volume of production which part will be directed to export to Asia-Pacific countries.

\footnotetext{
* Novatek and Fund of the Silk Way signed final binding agreements on the project of Yamal LNG. [Online] Available: https://neftrossii.ru/content/novatek-i-fond-shelkovogo-puti-podpisali-okonchatelnye-obyazyvayush chie-soglasheniya-po-proektu-yamal$\underline{\operatorname{spg}}$ (November 24, 2017)
} 


\section{Results of the research}

In Asia - Pacific region there are five largest gas importers: China, Japan, India, Korea and Taiwan. In three years the indicator of natural gas import considerably grew: in China for 0,8\%, in Japan for 0,95\%, in South Korea for $1,05 \%$ (see Figure 1).

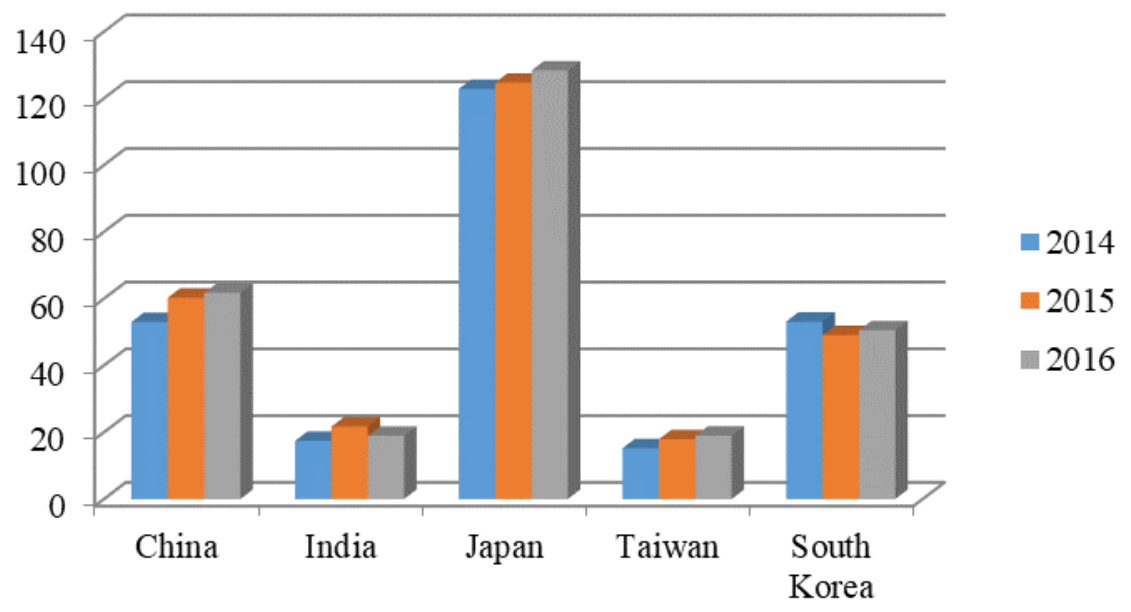

Fig. 1. Natural gas import, billion cubic meters Source: https://www.eia.gov/beta/ international/

South Korea is the country dependent on LNG supply, considerably increasing a consumption indicator every year. For India gas import allows to reduce deficit between amount of the consumed and made gas. The energy policy of China optimizes structure of energy industry towards gradual increase in a share of natural gas and also a flared cooperation with Russia recently (see Figure 2).

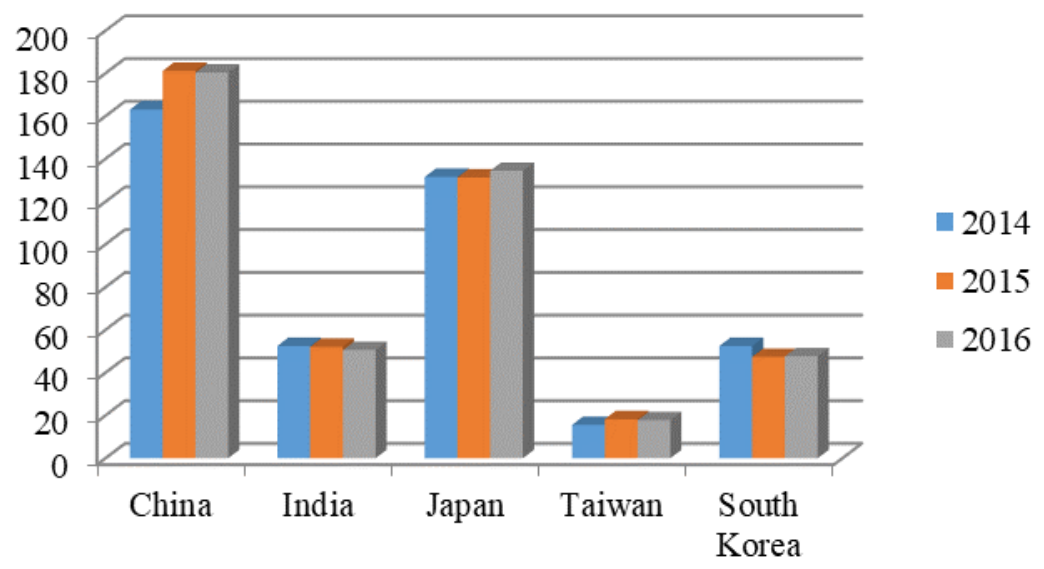

Fig. 2. Consumption of natural gas, billion cubic meters Source: https://www.eia.gov/beta/ international/

As a rule, the future of the project of gas transportation to Asia-Pacific countries, is determined by the signed contracts and implementation of energy projects. For Russia the cooperation with Asia-Pacific countries has trade and investment value. At the same time a key source for export are energy resources of the Far East. In this region concentrated more than 14\% of inventories of oil (about 4 billion tons) and 17\% of natural gas (or 42 trillion 
cubic meters). Degree of competitiveness of the territories of the Far East is determined by the existing projects which at the present stage already bring result. One of them - "Sakhalin-II" (Sakhalin Energy). Two main processing lines annually receive about 14,9 billion cubic meters of liquefied natural gas, 11 million tons from which it is exported to the countries of Asia - Pacific region. The project is aimed first of all at gas markets of Japan and South Korea. In 2017 "Sakhalin Energy" plans to construct the third processing line which capacity will make about 5,4 million tons/years.

The new stage of a cooperation of the "Gazprom" and "CNPC" company concerning supply of gas through Altai to China on the force of "Siberia-2" project (Western route) are begins. Many experts assume, that export size will reach 30 billion cubic meters a year. The project construction presumably will begin in 2020. Until "Gazprom" with the Chinese company came to the mutually advantageous contract, however, this project is profitable to China as a part of infrastructure is already created, and the breakeven point of gas projects of Gazprom is rather low ${ }^{\dagger}$.

In addition, in 2014 the "Gazprom" company signed with the "CNPC" company the contract for 30 years for delivery to China of 38 billion cubic meters a year on "The Force of Siberia" project (East route). At the beginning of March, 2017 it became known that the project considerably extended thanks to the allocated investments into 158,8 billion rubles. China is interested in Russian gas supplies, generally to three provinces of the northeast: Heilongiiang, Jilin and Liaoning which have deficiency not only in gas, but also in oil (see Figure $3)$.

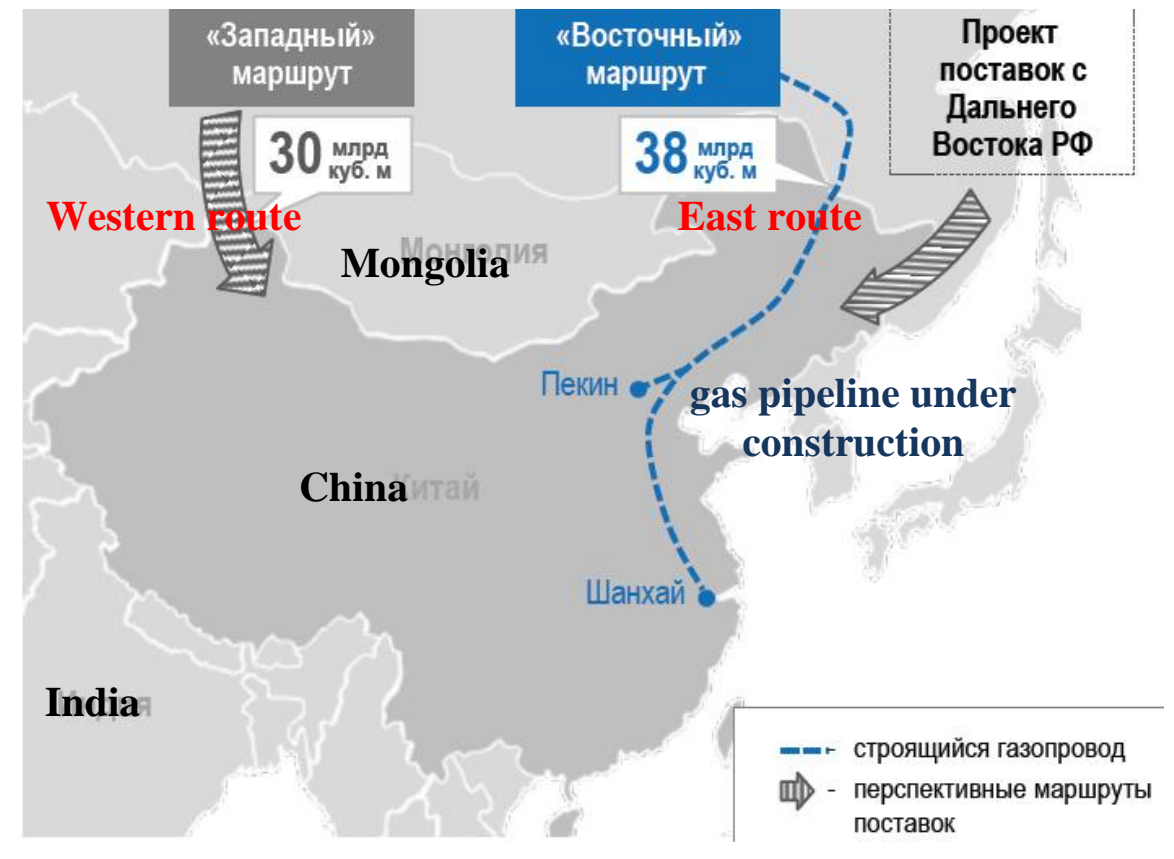

Fig. 3. Directions of supply of gas from Russia to China

Source: http://www.gazprom.ru/f/posts/91/11594/presenttion-press-conf-2017-06-08-ru.pdf

\footnotetext{
${ }^{\dagger}$ CNPC is ready to build "Force of Siberia - 2". [Online] Available: http://www.vedomosti.ru/ business/articles/2016/06/15/645346-cnpcsilu-sibiri (November 23, 2017)
} 
China, as a result of a big flow of import of cheap oil, became the world center of oil processing owing to what China took the second place in 2017 the USA on capacity of oil refinery. According to some information, the Russian ESPO (Eastern Siberia Pacific Ocean) was demanded in the market of the Asia - Pacific countries, however China acts as the main buyer (see the Figure 4).

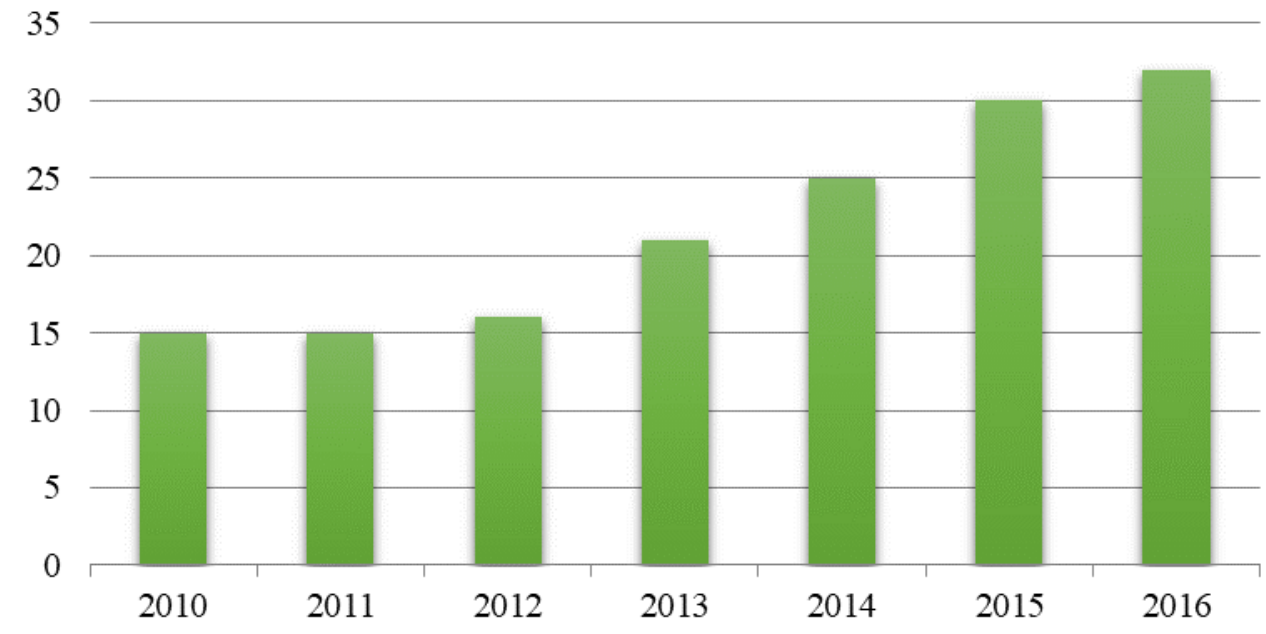

Fig. 4. Dynamics of deliveries of ESPO, one million tons Source: Anankina and Griaznov, 2017

According to "Rosneft" company, supply only of one oil to the Asia-Pacific countries grew by the beginning of 2017 by 8,6\% (about 43 million tons), not to mention gas. On March 8, 2017 the Minister of Energy of the Russian Federation A. Novak and India - Dkharmendra Pradkhan discussed joint energy cooperation in projects on the Arctic shelf of Russia and future deliveries of the Russian gas to India. In case of the growing demand for gas in the Indian market and perspective projects in Russia, interest of India purchased strategic nature

Development of the "Sakhalin" projects in the Far East will allow not only to increase twice deliveries to AsiaPacific countries and also to win the competition in the market of LNG against the prime vendor of gas and developing in this sector - Australia. In 2016 "Sakhalin-I" and "Sakhalin II" delivered on the Asian market about 12 million tons of LNG a year, from them more than 70\% - to Japan.

In April, 2017 it became known that the energy relations between Russia and Japan move to a new level, in connection with project development "Sakhalin-III". The project is planned to be started in 2022. Project implementation will allow Japan to receive gas 2,5 times cheaper than LNG in the world market. So, "Japan Pipeline Development and Operation" (JPDO) and "Japan Russian Natural Gas" (JRNG) develop the plan of the gas pipeline "Sakhalin-Hokkaido" through which gas of more than 20 billion cubic meters a year will be delivered. Length will reach 1,5 thousand $\mathrm{km}$ to Tokyo, the cost of such project will constitute about 5,5 or 6 billion dollars (see the Figure 5).

\footnotetext{
* Russia and India agreed about work on the shelf of the Russian Federation. [Online] Available: http://www.vestifinance.ru $\underline{\text { /articles/82291 (November 21, 2017) }}$
} 
According to experts of "JPDO" the construction of the gas pipeline will be profitable to both parties: the project will be in great demand, than was planned (about 25 billion cubic meters of gas instead of 20 billion cubic meters). At the same time, these assumptions rely on the fact that Japan - the largest world consumer of LNG, and it is possible that purchase of gas on a long-term stable basis, will lead to expansion of demand.

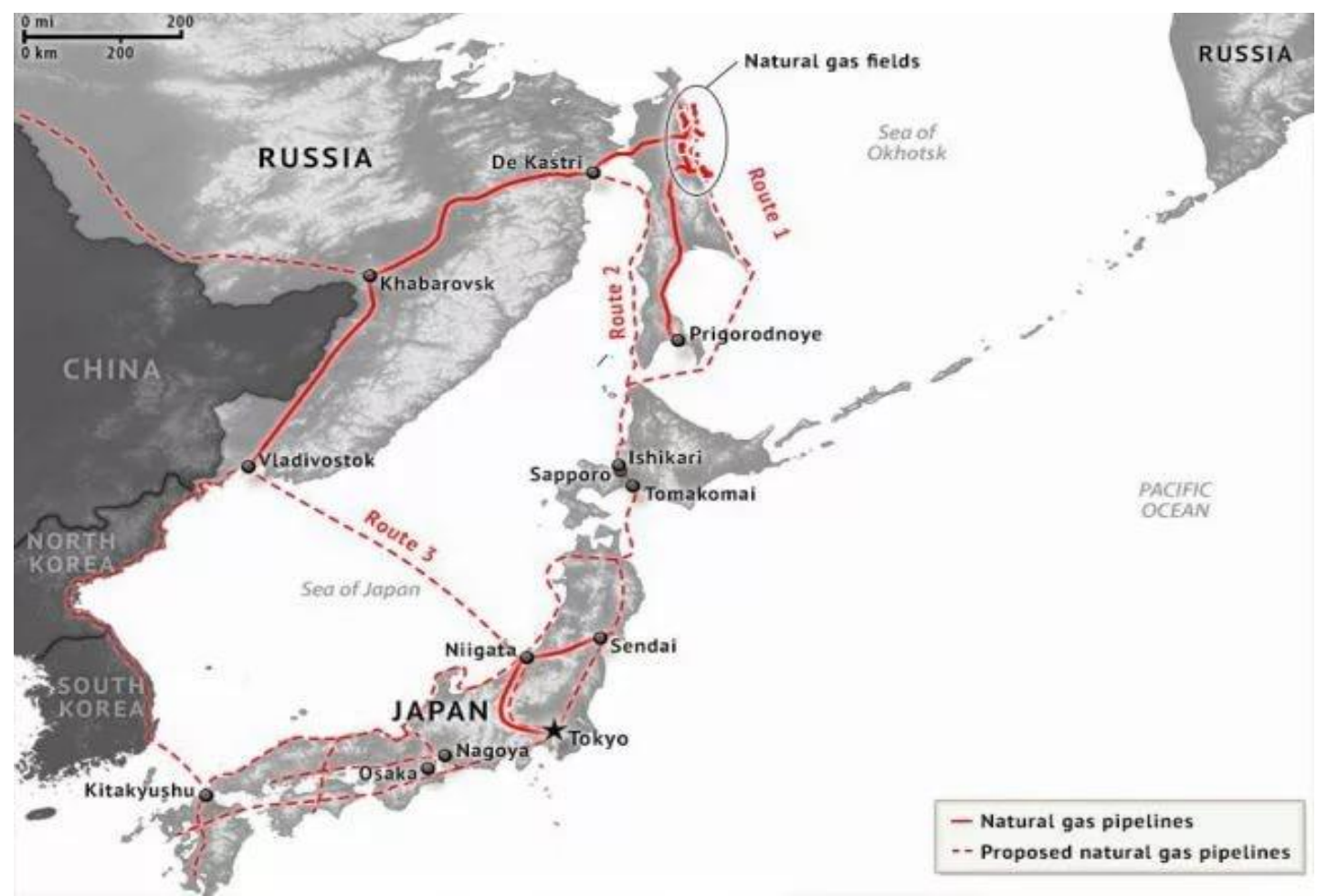

Fig. 5. Project plan of "Sakhalin-Hokkaido-Tokyo" Source: http://edo-tokyo.livejournal.com/5796034.html

Profitability of the project is estimated by ROE coefficient (profitability of an equity) more than in $20 \%$, not only own financing by consortium, but also attraction to participation of the leading foreign enterprises, investors and credit institutions is also supposed.

Fields of the project of "Gazprom" will become resource base - "Sakhalin-III" which inventories are estimated at 1,4 trillion cubic metres, also a source of raw materials the Japanese companies would like to see Eastern Siberia with inventories in 3,2 trillion cubic metres and the "Sakhalin-I" field from 500 billion cubic meters. Discussions about purchases of gas about the last two fields are conducted by the companies for many years. At present Japan buys about $80 \%$ of the Russian gas from the field of "Sakhalin-II".

By calculations of "Japan Russian Natural Gas" if transportation constitutes 25 billion gas in the form of LNG, then costs for liquefaction will be about 18 billion dollars. Therefore, the price taking into account costs for transport, for liquefaction, regasification and delivery will constitute 5 dollars / MMBtu, and the cost of pipeline gas of only 2 dollars / MMBtu. By calculations of experts, income from transportation will constitute about 1,5 billion a year, operating expenses about 500 million a year, revenue about 1 billion dollars, a net income about 
670 milion dollars. According to "Japan Pipeline Development and Operation", the project has high profitability, as confirm this financial performance . $^{\text {. }}$

South Korea also takes the dominating position in a number of importers in the LNG world market. Increase in demand in South Korea is explained by growth of industrial production and the low price of gas. A benefit of the gas market of South Korea - the developed internal gas transmission network connecting the LNG coastal terminals to the main points of consumption of energy resources. However, the gas market of the country completely depends on gas import. Agreements on supply of the Russian LNG to Korea were reached at the beginning of 2008. In 2011 "Gazprom" and the South Korean company - "KOGAS" signed the road map. Total length of the gas pipeline was estimated at 1,1 thousand km., from them $700 \mathrm{~km}$ - through North Korea. The construction cost of such gas pipeline through the territory of DPRK was originally estimated at 2,5 billion dollars. $^{* *}$

In 2017 it became known that the Korean state corporation "KOGAS" conducts negotiations with "Gazprom" on increase in purchases of gas. While South Korea isn't carried to large buyers of the Russian LNG, however, the deputy minister of trade, the industry and power - In Taychi said that with fall of cost of gas, the Russian LNG became the cheapest and attractive resource in South - East Asia ${ }^{\dagger \dagger}$.

The main supply of gas to Korea is performed with LNG - the "Sakhalin Energy" plant. In 2016 to Korea it was delivered by order of 1,9 million tons LNG (17\% of general LNG production - the plant), however this year according to the plan Korea will increase purchasing amount approximately to 2,5 million tons, to 2020 - up to 7 million tons (considering rapid growth of demand and that fact that search of resources on the shelf to Koreas didn't yield results). Increase of a role of the Far East in providing Asia-Pacific countries with gas are provided in Table 2.

Table 2. Forecast data of gas export from Russia to Asia-Pacific countries, billion cubic meters

\begin{tabular}{|c|c|c|c|c|}
\hline \multirow{2}{*}{ Countries } & \multicolumn{3}{|c|}{ Years } \\
\cline { 2 - 5 } & 2015 & 2020 & 2025 & 102 \\
\hline China & 40 & 78 & 10 & 165 \\
\hline Japan & 5 & 7 & 17 & 2030 \\
\hline South Korea & 10 & 8,5 & 10,3 & 10,3 \\
\hline to other Asia-Pacific \\
countries
\end{tabular}

Source: Pogosian, 2017

\footnotetext{
$\S$ Mordyushenko O., Skorlygina N. (2017). Japan calculated the road to Russia. [Online] Available: http://www.kommersant.ru/doc/3248653 (November 26, 2017)

${ }^{* *}$ The Russian gas is capable to unite two Koreas. [Online] Available: https://vz.ru/economy/2017/ 7/6/877593.html (November 26, 2017)

$\dagger$ Pogosian A. (2017). South Korea will fight for the Russian gas. [Online] Available: https://iz.ru/612602/arsenii-pogosian/koreianamerena-narastit-zakupku-spg-u-gazproma-do-10-mln-tonn (November 23, 2017)
} 
The International Journal

ENTREPRENEURSHIP AND SUSTAINABILITY ISSUES

ISSN 2345-0282 (online) http://jssidoi.org/jesi/

2018 Volume 5 Number 3 (March)

http://doi.org/10.9770/jesi.2018.5.3(11)

\section{Conclusion}

The competition in the world gas market (especially it is connected with development of the energy sector in the Middle East) doesn't allow to say, that Russia is the largest suppliers in the market of Asia-Pacific countries. Nevertheless, interest in the Russian energy resources in the Asian market constantly grows. China, Japan and other countries of this region are already present at an energy portfolio of the Russian gas companies. It is connected with a geographical location of Russia, with high inventories of hydrocarbons in the Far East, safety of deliveries, low policy risks, etc. In other words, the Russian market of energy carriers in this region is quite predictable that can't be told about suppliers of energy carriers from other countries.

Projects of Russia are competitive even in case of the low prices of gas, for example, the "Yamal - LNG" project. Now breakeven price of this project makes $5-6$ dollars/one million of the britain-thermal units (BTU) whereas at the beginning of 2017 the prices of LNG in the Asia- Pacific countries constituted 7,5 dollars/one million of BTU. Russia is capable to bring about 10 more projects which have chances of implementation till 2030 to the market. First of all, it concerns projects of the Far East LNG and the "Vladivostok - LNG" project. Thus, the RussianAsian relations in the energy sphere become stronger, and it is possible that in the future Russia will be able to take the place of the large supplier in the market of the Asia - Pacific countries.

\section{References}

Anankina E., Griaznov A. (2017). Can The U.S. Shut Off Russia's Gas Supply To Europe?. [Online] Available: https://www.spglobal.com/our-insights/Can-The-US-Shut-Off-Russias-Gas-Supply -To-Europe.html (November 23, 2017)

CNPC is ready to build "Force of Siberia - 2". [Online] Available: http://www.vedomosti.ru/ business/articles/2016/06/15/645346-cnpcsilu-sibiri (November 23, 2017)

Entry into the markets of Asia-Pacific countries. [Online] Available: http://www.gazprom.ru/f/posts/91/114594/presentation-press-conf2017-06-08-ru.pdf (November 26, 2017)

International Energy Information. [Online] Available: https://www.eia.gov/beta/ international/ (November 24, 2017)

Japan estimated a gas pipeline construction Sakhalin-Hokkaido at $\$ 6$ billion. . [Online] Available: $\underline{\text { http://edo- }}$ tokyo.livejournal.com/5796034.html (November 26, 2017)

Kutuzova M. (2016). Arctic: from plans before development. Oil of Russia (11 - 12): 37-42.

LNG - the battle of Asia: why promise Russia a victory over the USA. [Online] Available: https://eadaily.com/ru/news/2016/12/16/spgbitva-za-aziyu-pochemu-rossii-obeshchayut-pobedu-nad-ssh (November 23, 2017)

Melas, V.; Lisin, E.; Tvaronavičienè, M.; Peresadko, G.; Radwański, R. (2017). Energy security and economic development: renewables and the integration of energy systems, Journal of Security and Sustainability Issues 7(1): 133-139. https://doi.org/10.9770/jssi.2017.7.1(11)

Mordyushenko O., Skorlygina N. (2017). Japan calculated the road to Russia. [Online] Available: http://www.kommersant.ru/doc/3248653 (November 26, 2017)

Novatek and Fund of the Silk Way signed final binding agreements on the project of Yamal LNG. [Online] Available: https://neftrossii.ru/content/novatek-i-fond-shelkovogo-puti-podpisali-okonchatelnye-obyazyvayushchie-soglasheniya-po-proektu-yamalspg (November 24, 2017) 
The International Journal

ENTREPRENEURSHIP AND SUSTAINABILITY ISSUES

ISSN 2345-0282 (online) http://jssidoi.org/jesi/

2018 Volume 5 Number 3 (March)

http://doi.org/10.9770/jesi.2018.5.3(11)

Pogosian A. (2017). South Korea will fight for the Russian gas. [Online] Available: https://iz.ru/612602/arsenii-pogosian/koreianamerena-narastit-zakupku-spg-u-gazproma-do-10-mln-tonn (November 23, 2017)

Production natural and associated petroleum gas. [Online] Available: http://minenergo.gov.ru/node/1215 (November 26, 2017)

Russia and India agreed about work on the shelf of the Russian Federation. [Online] Available: http://www.vestifinance.ru /articles/82291

(November 21, 2017)

The Gazprom constructed 500 km of "Force of Siberia". [Online] Available: http://www.vestifinance.ru/articles/ 81989 (November 21, 2017)

The Russian gas is capable to unite two Koreas. [Online] Available: https://vz.ru/economy/2017/ 7/6/877593.html (November 26, 2017)

Tvaronavičienè, M.; Nesterova, K.; Kováčik, V. (2017). Energy security and long-term energy efficiency: case of selected counties, Journal of Security and Sustainability Issues 7(2): 349-357. https://doi.org/10.9770/jssi.2017.7.2(14)

\author{
Larisa SHAKHOVSKAYA \\ ORCID ID: 0000-0002-3700-2435 \\ Elena PETRENKO \\ ORCHID ID: 0000-0001-6892-2392 \\ Victoria TIMONINA \\ ORCHID ID: 0000-0003-2344-6497
}

Register for an ORCID ID:

https://orcid.org/register

\footnotetext{
Copyright (C) 2018 by author(s) and VsI Entrepreneurship and Sustainability Center

This work is licensed under the Creative Commons Attribution International License (CC BY).

http://creativecommons.org/licenses/by/4.0/

c. (i) Open Access
} 